https://doi.org/10.17048/AM.2020.271

\title{
Emri Zsuzsa
}

Eszterházy Károly Egyetem, Biológiai Intézet, Állattani Tanszék

emri.zsuzsanna@uni-eszterhazy.hu

Antal Károly

Eszterházy Károly Egyetem, Biológiai Intézet, Állattani Tanszék

antal.karoly@uni-eszterhazy.hu

\section{Csordás Georgina}

Eszterházy Károly Egyetem, Pszichológia Intézet

csordas.georgina@uni-eszterhazy.hu

Kvaszingerné Prantner Csilla

Eszterházy Károly Egyetem, Digitális Technológia Intézet

kvaszingerne.prantner.csilla@uni-eszterhazy.hu

\section{Kissné Zsámboki Réka}

Soproni Egyetem, Neveléstudományi és Pszichológiai Intézet, Humáninformatika Tanszék kissne.zsamboki.reka@uni-sopron.hu

\section{EEG mérés pedagógiai alkalmazási lehetőségei}

\begin{abstract}
Absztrakt
A hordozható, könnyen használható elektroencefalográfok (EEG) segítségével a kognitív folyamatokat úgy vizsgálhatjuk, hogy a természetes viselkedést alig befolyásoljuk. A hajas fejbőrön mért idegi aktivitás mikrovoltos nagyságrendű, emiatt az izomaktivitásból, szemmozgásból származó mútermékektől meg kell tisztítani. Ezeknek a mútermékeknek a tökéletes eltávolítására még nincs megfelelő megoldás, emiatt az EEG-t fóleg olyan feladatokhoz érdemes használni, amelyek nem járnak sok izomaktivitással. E kötöttség ellenére a pedagógia számos területén sikeresen alkalmazták már az EEG-t. A különböző feladatok alatt mért agyi aktivitásokból a feladatok alatti figyelemre, kognitív terhelésre és a feladatmegoldási stratégiákra tudtak következtetni. Sajátos nevelési igényű gyerekek-
\end{abstract}


nél neurofeedback módszerrel segítik az önreguláció és a megfelelő viselkedés kialakítását. Különböző személyek agyi aktivitásának szinkronizációja pedig a szociális közelséggel és az információ átadás sikerével van kapcsolatban. Ezek az alkalmazások az EEG spektrális jellemzőinek követésén alapulnak. Fourier transzformációval az EEG jelet különböző frekvenciájú összetevőire bontják, és meghatározzák az egyes frekvenciák arányát a teljes aktivitásban. A humán hajas fejbőrről az $\alpha$ tartomány nagy biztonsággal regisztrálható. Habár ezt a hullámot az inaktivitással hozzák kapcsolatba leginkább, az irányított figyelem kialakításában is kulcsfontosságú szerepe van, a feladat szempontjából zavaró információt $\alpha$ aktivitás segítségével nyomjuk el. Kísérleteimben a különböző feladatok alatt az egyes elektródákkal regisztrált $\alpha$ aktivitás mértéke karakterisztikus mintázatot mutatott. Az $\alpha$ aktivitás legmagasabb occipitálisan volt relaxáció alatt, a kognitív terheléssel pedig csökkent, főleg frontálisan. Ez az aktivitási mintázat nem mindenkire volt jellemző, néhány résztvevőnél a relaxáció alatti $\alpha$ aktivitás növekedés még occipitálisan sem volt regisztrálható. Emiatt az EEG adatok interpretációjához az egyéni jellegzetességek felderítése elengedhetetlen. Az eddigi eredmények alapján az EEG pedagógiai alkalmazása ígéretesnek tűnik, érdemes alkalmazási spektrumát bővíteni a pedagógiai kutatási programokban.

Kulcsszavak: EEG, Fourier spektrum, neurofeedback, kognitív aktivitás

\section{The use of EEG measurements in Pedagogyvizuális visszacsatolás}

Portable, inexpensive, and easy-to-use electroencephalography (EEG) devices allow the examination of cognitive processes without a dramatic interference with normal ongoing behaviors. The scalp EEG signal amplitude is in the microvolts range and it is easily contaminated with different artifacts, such as ocular or muscle activities. Artifact removal has not been resolved satisfactory, therefore the use of EEG devices is limited to activities requiring minimal muscle activity. Despite this limitation several areas of pedagogy have already benefited from EEG measurements. Brain activities during different tasks provided information about engagement, mental workload, and cognitive strategies. Training in neurofeedback helped children with Special Educational Needs to maintain self-regulation and controll skills. Brain-to-brain synchrony measurements predicted the efficiency of information transfer, and showed social connectedness. These applications use the spectral analysis of the EEG signal. Fourier analysis decomposes the EEG into different sine waves and estimates the spectral power (which is proportional to the number of active neurons) at each frequency. From the human scalp $\alpha$ wave can be recorded the most reliably. Although this activity is mainly associated with iddleness, it is also important to maintain focus by blocking unwanted sensory processes. In our experiments $\alpha$ ?]power showed characteristic differences among tasks. It was the highest occipitally during relaxation and it decreased especially frontally with cognitive engagement. Tasks requiring similar 
mental activity showed similar $\alpha$ ? power distribution. Individuals might showed EEG activity with distinct characteristics, forexample some participants did not have increased $\alpha$ power during relaxation. Therefore the reliable interpretation of EEG requires the consideration of individual differences as well. In conclusion, application of EEG in pedagogy is promising, and it is worth considering its incorporation into educational research programs.

Keywords: cognitive activity, EEG, Fourier spectrum, neurofeedback

\section{Bevezetés}

A könnyen felhelyezhető, olcsó EEG készülékek és a digitalizált EEG jelek automatizált elemzését lehetővé tevő protokollok megjelenésével az EEG mérések felhasználási köre jelentősen bővült (Noreika és tsai, 2020; Turner és tsai, 2017). Pedagógiában az EEG alkalmazása ígéretesnek tűnik többek között a kisgyermekkori fejlődés sajátosságainak tanulmányozásánál (Bell és Cuevas, 2012; Mak és tsai, 2018), a különleges bánásmódot igénylő (SNI) gyermekek fejlesztésénél (Csordás, 2020; Hurt és tsai, 2014), illetve osztálytermi oktatásnál a figyelem, terhelés alakulásának mérésére (Antal és tsai, 2017; Klimesch, 2012; Tao és tsai, 2019). EEG aktivitás elemzésével segíthetjük olyan pedagógiai eljárások kidolgozását, amelyek az egyes tanulók egyénre szabott fejlesztését célozzák, vagy pedagógiai módszerek hatékonyságát határozzák meg.

\section{EEG és a kogníció kapcsolata}

Az EEG-elektródok a neocortex rétegeiben elhelyezkedő nagyszámú piramissejt szinkron aktivitását érzékelik. Az EEG készülék időbeli felbontása jó, térbeli felbontása kevésbé. A térbeli felbontás bizonyos mértékig az elektródok számával növelhető, de a neuronokat körülvevő folyadék tér alacsony ellenállása miatt a neuronból kiáramló töltések könnyen szétoszlanak az idegsejt környezetében, emiatt a kibocsátás forrása nehezen lokalizálható. Az EEG elektródok több ezer neuron szinkron aktivitását tudják érzékelni a fejbőrön keresztül. A szinkronizáció kialakításában a talamusznak és a neocortex lokális neuronhálózatainak van kitüntetett szerepe. A szinkronizáció kialakításában gátló neuronok játszanak fontos szerepet, segítségükkel történik a piramissejtek aktivitásának megfelelő időzítése. Nagyszámú piramissejt aktivitásának időbeli fluktuációja képezi a különböző frekvenciájú neuronális oszcillációk alapját, amelyek biztosítják, hogy a különböző külső és belső forrásokból folyamatosan érkező jelekből időben strukturált információ csomagok alakuljanak ki (Buzsáki és Watson, 2012). Az EEG elvezetéseken megjelenő neuronális oszcillációkat frekvenciájuk alapján csoportosítjuk. Az egyes oszcilláció típusok kognitív folyamatokban betöltött funkciója eltérő, megjelenésük 
jellemző bizonyos idegrendszeri folyamatokra, illetve hiányuk, vagy szokatlan gyakoriságuk kóros állapotokra utalhat (Basar, 2013).

A $\delta$ hullám (1-4Hz) felnőttekben dominánsan alvás alatt jellemző, gyerekekben ébren is előfordul, és általában csökkent agyi tevékenységre utal. Ébrenlétkor rövid időre a frontális lebenyhez köthető kognitív feladatok alatt is megjelenik, más gyorsabb oszcillációkkal kapcsoltan. A $\theta$ hullám $(4-8 \mathrm{~Hz})$ a hippocampusra és a környező limbikus struktúrákra jellemző, az epizodikus és téri memória kialakításában játszik szerepet. A neocortexben a munkamemória kialakításánál jelenik meg, illetve a prefrontális kéregben a viselkedési válasz értékeléséhez kapcsolódik. Felnőtteknél fáradtság esetén a frontotemporális régióról vezethető el, gyermekeknél a serdülőkor idejére jellemző aktivitás (Wang, 2010). Az $\alpha$ hullám (8-13Hz) a nyugodt éber állapot jellemző aktivitása, különösen csukott szem mellett jelentkezik a parietális és occipitális lebenyek fölött. A nyugalmi $\alpha$ laktivitáson kívül egy úgynevezett funkcionális $\alpha$ aktivitás is létezik, amely a szenzoros információk kódolásában és az irányított figyelem kialakításában játszik szerepet (Ketz és tsai, 2015). A $\beta$ hullám (13-30Hz) az éber, figyelmi állapotra jellemző, kis amplitúdójú gyors potenciálokból áll, amelyek a szenzori-motoros integrációban fontosak (Wang, 2010). A y hullámok $(30-80 \mathrm{~Hz})$ a figyelemhez kapcsolódnak, fontos szerepük van a különféle forrásból érkező jelek integrálásában (Wang, 2010). A tanulási folyamatokhoz, figyelemhez tulajdonképpen mindegyik hullámforma kötődik, az olcsó, hordozható készülékekkel leginkább a $\theta$, $\alpha$ és $\beta$ aktivitás változását lehet követni.

\section{EEG aktivitás elemzése}

EEG aktivitás mérésekor az agy elektromos jeleit kívánjuk rögzíteni, majd elemezni. Az agyi jelek alacsony amplitúdója miatt a felvételre kerülő mútermékek (más forrásokból származó elektromos jelek, például izomaktivitás, szemmozgás) a kiértékelést megnehezítik, bizonytalanná teszik. A mérés során a mútermékek megjelenését fontos minimalizálni, de teljesen kiiktatni őket általában nem tudjuk, emiatt az EEG jelek kiértékelésénél valamilyen formában csökkentenünk kell zavaró hatásukat. Ennek legegyszerúbb módja, ha pontosan időzített rövid feladatok ismétlésével az agyi elektromos jelet a mútermékekhez képest felerősítjük. Ez az eljárás nem minden esetben alkalmazható, a pedagógiai alkalmazásoknál általában folyamatosan követjük az agyi aktivitást a kiadott feladatok alatt, és annak változásaiból következtetünk a vizsgált személy kognitív állapotára. Ilyenkor a kívánt elemzés típusától függően a mútermékek időbeli vagy frekvenciatartomány szerinti elválasztását, esetleg az elektródák közötti eltéréseken alapuló eljárásokat használhatunk (Tejutak és tsai, 2014; Picurik és tsai 2007; Wang és tsai, 2014).

A mútermékek eltávolítása után általában a regisztrátumok Fourier spektrumát készítik el. Egy regisztrátum Fourier spektruma azt mutatja meg, hogy a különböző frekvenciájú EEG hullámok milyen 
arányban találhatók meg az elvezetésben egy adott időtartományban, például egy kiadott feladat alatt. A Fourier spektrum időbeli változását úgy jeleníthetjük meg, ha a spektrumot adott hosszúságú időablakokban készítjük el, és ezeket az ablakokat átfedéssel csúsztatjuk végig a teljes regisztrátumon (1. ábra).

1. ábra Egy feladatsor alatt rögzített EEG aktivitás (bal fent), az egyes feladatok alatti EEG Fourier spektrumai (jobb oldal) és a Fourier spektrum időbeli változása (bal lent).
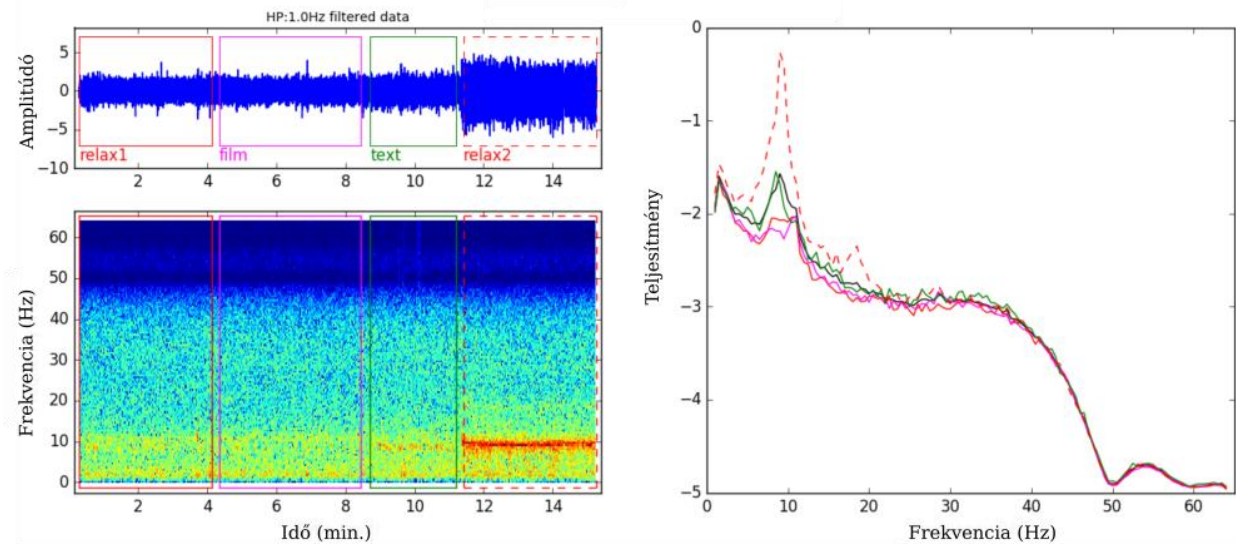

A Fourier spektrumon láthatunk egy csúcsot $10 \mathrm{~Hz}$ körüli frekvencia értéken, vagyis az $\alpha$ tartományban. Ez különösen becsukott szemmel emelkedik ki (relax2 = piros szaggatott vonal) az occipitális elektródokon. A többi feladat alatt az $\alpha$ csúcs amplitúdója alacsonyabb, de ennél a résztvevőnél olvasás (text = zöld vonal) alatt is elkülöníthető, és magasabb mint nyitott szemű relaxáció alatt (relax1 = piros vonal) (2. ábra).

\section{Az EEG néhány pedagógiai alkalmazása}

A XXI. század tanuláselméletei egyre inkább építenek a neurobiológia eredményeire, felhasználják azokat az ideális tanulási feltételek megteremtéséhez, és a tanulási folyamat minél hatékonyabb szervezéséhez. Ebben segíthet az EEG alkalmazása, mivel lehetővé teszi a tanulás alatti agyi aktivitások követését.

\section{Kisgyermekkori idegrendszeri fejlődés követése}

A gyerekek hatékony tanulási képességgel születnek, de ez a képességük szociálisan erősen beágyazott, többek között függ a tanulási környezettől és a személyes kapcsolatok minőségétől. A gyerekeknél az érés, fejlődés természetes folyamatát nem siettetni, hanem gazdagítani kell (Kissné, 2020). A fejlődés nyomon követéséhez és a tanulási képességek méréséhez a köznevelési intézmé- 
nyek számos klasszikus eljárást alkalmaznak, amelyek mellett a XXI. század új technikai vívmányai is egyre hangsúlyosabb szerepet kaphatnak. Nemzetközi kutatások alátámasztják, hogy mobil EEG készülékekkel történő vizsgálatok során feltárhatók például a diszlexia hátterében álló tanulási nehézségek, illetve - az eltérő agyhullám mintázatok miatt - elkülöníthetők a tudatos és tudattalan tanulási típusok (Kissné és Farnady-Landerl, 2018). További lehetőségként felmerült az a kérdés is, hogy a mobil EEG készülékek segítségével azonosíthatók-e olyan jellegzetes agyhullám-mintázatok, amelyek a különböző pedagógusi interakciók, nevelői attitűdök következményei. A pedagógiai nevelési és oktatási módszerek hatásrendszerének vizsgálata során előtérbe kerülhet az agyhullámok egymásra hangolódásának kérdésköre. A beszédfeldolgozás folyamatában a jelenlegi modellek egy jósló, előfeldolgozó fázist és az aktuálisan érkező nyelvi információ feldolgozásának fázisát különítik el. Az információátadás mértéke függ az előfeldolgozó fázis sikerességétől, minél jobban tudjuk előre jelezni az aktuális beszédtartalmat annál jobb lesz a megértés. Ezt a sikert a beszélő és a hallgatóság szuperior temporális lebeny Wernicke áreát (beszédértő központ) is tartalmazó részéről regisztrált agyhullámainak szinkronitásával lehetett előre jelezni (Dikker és tsai, 2014).

Az EEG mérések gyermekkorban történő alkalmazását nagyban korlátozza, hogy a mérés kiértékelését az izomaktivitásból származó mútermékek megnehezítik, ezért nem minden típusú aktivitás alatt alkalmazható. Nyugalomban, vagy filmnézés közben rögzített EEG aktivitásokból viszont megbízható következtetéseket lehetett levonni, az ismételt mérések hasonló eredményekhez vezettek (Noreika és tsai, 2020). Így érdekes és újszerű kutatási terület lehet a mese- vagy zenehallgatás hatásának vizsgálata a gyermekek érzelmi állapotára és az ismeretelsajátítási folyamatok eredményességére. A bioinformatika vívmányai, a mobil EEG készülékek és a hozzá hasonló eszközök alkalmazása a gyermeki fejlődés és tanulási képességek mérésében még nagyon távolinak tűnhet. Érdemes azonban felhívni a kutatók és a pedagógiai közvélemény figyelmét azokra az interdiszciplináris kapcsolódási pontokra, amelyek a jövő generációi számára új gyakorlati implementációk sorát nyithatják meg (Kissné és Farnady-Landerl, 2018).

\section{Neurofeedback módszer}

A gyermekek fejlesztésében egyre elterjedtebb a neurofeedback módszer alkalmazása, amely során a gyermek agyi aktivitását EEG készülékkel monitorozzák, és változásáról a gyermek számára vis-szajelzést küldenek (Antle és tsai, 2015; Martínez és tsai 2016). A regisztrált EEG adatokat többek között mesterséges intelligencia segítségével dolgozzák fel, és vitális információt nyernek a gyermek mentális állapotáról. A fejlesztéshez vizuális visszacsatolást használnak, gyakran valamilyen játékba építve jelennek meg a különböző mentális állapotokra utaló jelek, így a felhasználó folyamatos vissza- 
jelzést kap azokról. Ez a valós idejű visszajelzés segíti az érzelmi, figyelmi és relaxációs állapotok kontrollálását és elősegíti a kívánt állapotok elérését (Charmeur és tsai, 2012; Knox és tsai, 2011).

Gyermekek esetében különösen népszerú a visszacsatolás számítógépes játékokba ágyazása, mivel így a gyermekek motiváltsága, érzelmi bevonódása növekszik (Blandón és tsai, 2016). Az EEG jelek méréséhez a Neurosky (neurosky.com/biosensors/eeg-sensor/biosensors/), az Emotive Epoc (www.emotiv.com/epoc/) és az Emotiv Insight (https://www.emotiv.com/insight/) készülékeket alkalmazzák.

Egy Nepálban végzett kutatásban traumatizált, szegénységben élő gyermekeknél fejlesztettek önregulációt. A vizsgálatban a Neurosky EEG készüléket használták, valamint a Mind-Full (https://www.mindfullapp.ca/) nevű számítógépes játékot, amelyben a gyermeknek különböző feladatokat kell megoldani különböző agyi aktivitások (például figyelem) kontrollálásával, amelyekért a játékban jutalmakat kapnak. Eredményként elmondható, hogy a gyermekek önregulációja, viselkedése pozitív irányba változott, ezt az utánkövetéses viszgálat is alátámasztotta hat héttel később (Antle és tsai, 2015). Egy másik vizsgálatban Emotiv Insight segítségével az SNI-s gyermekek játékrobotokat tanultak meg irányítani neurofeedback technikával, ezzel fejlesztve az érzelmi regulációs és egyéb kognitív képességeket (Lekova és tsai, 2018).

\section{Különböző feladatok alatti aktivitás monitorozása}

A tanulás alatti különböző folyamatok mindegyikéhez jellegzetes agyi aktivitás és ezt jelző EEG hullámok kapcsolódnak. $\theta$ aktivitás jellemzi a kódolási folyamatot, és az emléknyomok felidézését (Tao és tsai., 2019). A munkamemória használatával járó feladatoknál a frontális $\theta$ aktivitás növekszik, a feladat szempontjából zavaró érzékszervi területekről érkező információ elnyomását pedig magasabb $\alpha$ aktivitás jelzi (Klimesch, 1999). Számolásnál $\theta$ aktivitás kíséri az aritmetikai tények memóriából történő előhívását, az $\alpha$ és $\delta$ aktivitás csökkenése pedig általánosan jellemzi a növekvő kognitív igénybevételt (Hinault és Lemaire, 2016). Már az $\alpha$ aktivitás vizsgálata is sokat elárul a különböző feladatokról (Kvaszingerné és Emri, 2018). Az a csúcs amplitúdója az egyes agyterületeken a különböző kognitív igénybevételt igénylő feladatoknál eltérő mintázatot mutatott (2. ábra). A csukott szemű relaxáció alatt (relax1-2) az alfa csúcs amplitúdója magas volt, különösen a látókéreg felett $(01,02)$, míg a nagyobb kognitív terhelést jelentő feladatoknál (olvasott szöveggel kapcsolatos kérdések megválaszolása = válasz; fejszámolás = matek) különösen a frontális területeken alacsony maradt. Ha a feladatsor alatt kétszer is előfordult csukott szemű relaxáció, az alattuk regisztrált EEG aktivitás hasonló volt, de nem teljesen azonos, mivel a nyugalomban is sok tényező hat az EEG-re, az állandónak tekinthető genetikai tényezők mellett még az éberségi állapot vagy a fáradság is. 


\section{2. ábra EEG spektrum alfa csúcs amplitúdója különböző elektródákon eltérő kognitív igénybevételt jelentő}

\section{feladatok alatt}

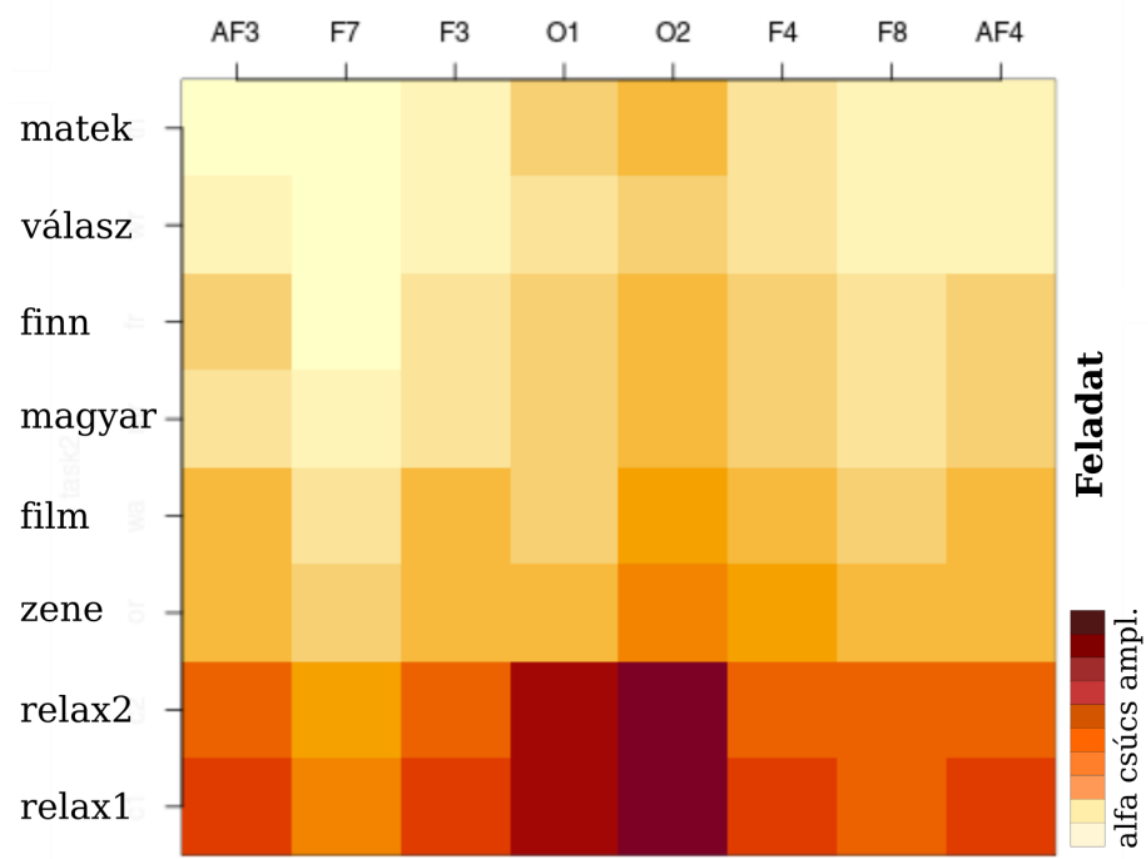

EEG csatorna

\section{Osztálytermi környezet sajátosságai}

A legtöbb mérés a különböző feladatok alatti EEG aktivitást laboratóriumi körülmények között vizsgálta. Ezek a mérések sokat elárulnak a figyelemről, kifáradásról, hatékonyságról, de nem tükrözik az osztálytermi tanulási körülményeket, ahol a feladatokat nem lehet szigorúan időzíteni, az egyes tevékenységek között folyamatos átmenet van. A mai technológia azt lehetővé teszi, hogy a $\beta, \alpha, \theta$ és $\delta$ aktivitásokat valós időben kövessük egy tanórán, de a jelenleg alkalmazott algoritmusok a valós idejú elemzéshez csak pár szempontot vesznek figyelembe, emiatt sokak szerint nem alkalmasak a tanuló figyelmi szintjének megbízható jelzésére osztálytermi keretek között.

\section{Összegzés}

Az EEG alkalmazása a fennálló nehézségek ellenére is ígéretesnek túnik a pedagógia különböző területein, a hordozható, egyszerúbb EEG készülékek alkalmazásával lehetőség nyílik az eddigi laboratóriumi eredmények valós környezetben történő ellenőrzésére is. Ez fontos lehet például az irányított 
tanulást megvalósító programoknál vagy neurofeedback protokollok alkalmazásánál. A hordozható EEG készülékek fontos eszközei lehetnek a pedagógiai stratégiák hatékonyság meghatározásának is, mivel segítségükkel a hatékony tanulási folyamatra jellemző idegi aktivitások kialakulása illetve gyakorisága követhetővé válik. Ráadásul, a valós környezetben végrehajtott mérések rávilágíthatnak olyan tanulási stratégiákra, vagy tanulást jelentősen befolyásoló tényezőkre is, amelyek fontossága eddig a laboratóriumi körülmények miatt rejtve maradt.

\section{Irodalomjegyzék}

Akeju Oluwaseun, Pavone Kara J., Westover M. Brandon, Vazquez Rafael, Prerau Michael J., Harrell Priscilla G., Hartnack Katherine E., Rhee James, Sampson Aarom L.vizuális visszacsatolás , Habeeb Kathleen, Gao Lei, Pierce Eric T., Walsh John L., Brown Emery N., Purdon Patrick L. (2014). A Comparison of Propofol- and Dexmedetomidine-induced Electroencephalogram Dynamics Using Spectral and Coherence Analysis. Anesthesiology. 121. 5. 978-989.

\section{https://doi.org/10.1097/ALN.0000000000000419}

Antal Károly, Kvaszingerné Prantner Csilla, Emri Zsuzsa (2017). What EEG can tell us about learning? Acta Academiae Paedagogicae Agriensis Nova Series: Sectio Biologiae. 44. 55-65.

Antle, Alissa N., Chesick, Leslie, Levisohn, Aaron, Sridharan Srilekha Kirshnamachari, Tan, Perry (2015). Using neurofeedback to teach self-regulation to children living in poverty. In: Proceedings of he 14th International Conference on Interaction Design and Children. pp. 119-128.

https://doi.org/10.1145/2771839.2771852

Başar Erol (2013). Brain oscillations in neuropsychiatric disease. Dialogues in Clinical Neuroscience. 15. 3. 291-300.

\section{https://doi.org/10.31887/DCNS.2013.15.3/ebasar}

Bell Martha Ann, Cuevas Kimberley (2012). Using EEG to Study Cognitive Development: Issues and Practices. Journal of Cognitive Development. 13. 3. 28-294.

\section{https://doi.org/10.1080/15248372.2012.691143}

Blandón Diego Zamora, Munoz John Edison, Lopez David Sebastian, Gallo Henao, Oscar (2016). Influence of a $\mathrm{BCl}$ neurofeedback videogame in children with ADHD. Quantifying the brain activity through an EEG signal processing dedicated toolbox. IEEE 11th Colombian Computing Conference (CCC).

\section{https://doi.org/10.1109/ColumbianCC.2016.7750788}


Buzsáki György, Watson Brendon O. (2012). Brain rhythms and neural syntax: implications for efficient coding of cognitive content and neuropsychiatric disease. Dialogues in Clinical Neuroscience. 14. 4. 345-367.

https://doi.org/10.31887/DCNS.2012.14.4/gbuzsaki

Csordás Georgina (2020). Az Emotive EPOC+ EEG készülék alkalmazásának lehetőségei különleges bánásmódot igénylő gyerekek fejlesztésében. Mesterséges Intelligencia - interdiszciplináris folyóirat. 2. 1. 71-82.

https://doi.org/10.35406/MI.2020.1.71

Dikker Suzanne, Silbert Lauren. J., Hasson, Uri, Zevin, Jason D. (2014). On the same wavelength: predictable language enhances speaker-listener brain-to-brain synchrony in posterior superior temporal gyrus. The Journal of Neuroscience. 34. 18. 6267-6272.

\section{https://doi.org/10.1523/JNEUROSCl.3796-13.2014}

Ducharme Peter, Wharff Elizabeth, Hutchinson Eliza, Kahn Jason, Logan Grace és GonzalezHeydrich Joseph (2012). Videogame assisted emotional regulation training: an ACT with RAGE-control case illustration. Clinical Social Work Journal. 40. 1. 75-84.

\section{https://doi.org/10.1007/s10615-011-0363-0}

Hinault, Thomas, Lemaire, Patrick (2016). What does EEG tell us about arithmetic strategies? A review. International Journal of Psychophysiology. 106. 115-26.

https://doi.org/10.1016/j.ijpsycho.2016.05.006

Hurt Elizabeth, Arnold L. Eugene, Lofthouse Nicholas (2014). Quantitative EEG neurofeedback for the treatment of pediatric attention-deficit/hyperactivity disorder, autism spectrum disorders, learning disorders, and epilepsy. Child and Adolescent Psychiatric Clinics of North America. 23. 3. 465-486.

\section{https://doi.org/10.1016/i.chc.2014.02.001}

Ketz Nicholas A, Jensen Ole, O'Reilly Randal C. (2015). Thalamic pathways underlying prefrontal cortex-medial temporal lobe oscillatory functions. Trends in Neurosciences. 38. 1. 3-12.

https://doi.org/10.1016/j.tins.2014.09.007

Kissné Zsámboki Réka, Farnady-Landerl Viktória (2018). Neuropedagógiai innovációs lehetőségek a neveléstudományi kutatásokban az EMOTIV EPOC+ mobil EEG készülék alkalmazásával. Képzés és Gyakorlat. 16. 3. 21-35.

\section{https://doi.org/10.17165/TP.2018.3.3}

Kissné Zsámboki Réka (2020). A kisgyermekkori matematikai kompetenciákról alkotott nézetek változása. Gyermeknevelés. 8. 1. 75-82.

https://doi.org/10.31074/gyntf.2020.1.75.82 
Klimesch, Wolfang (1999). EEG alpha and theta oscillations reflect cognitive and memory performance: a review and analysis. Brain Research Reviews. 29. 169-195.

https://doi.org/10.1016/S0165-0173(98)00056-3

Klimesch Wolfgang (2012). $\alpha$-band oscillations, attention, and controlled access to stored information. Trends in Cognitive Sciences. 16. 12. 606-617.

https://doi.org/10.1016/j.tics.2012.10.007

Knox M., Lentini J., Cummings T. S., McGrady A., Whearty K., Sancrant, L. (2011). Game-based biofeedback for paediatric anxiety and depression. Mental Health in Family Medicine. 8. 3. 195.

Kvaszingerné Prantner, Csilla, Emri, Zsuzsanna (2018). Hogyan támogatható a tanulás vizsgálat Emotiv EPOC EEG eszközzel? In: AgriaMedia 2017. 2017.10.11-13., Eger.

https://doi.org/10.17048/AM.2018.157

Lekova Anna, Dimitrova Maya, Kostova Snezhanka Bouattane Omar, Ozaeta Leire (2018). BCl for Assessing the Emotional and Cognitive Skills of Children with Special Educational Needs. In 2018 IEEE 5th International Congress on Information Science and Technology (CiSt). (pp. 400-403.)

https://doi.org/10.1109/CIST.2018.8596571

Mak Veronika, Szecsi Tünde, Varga László (2018). Overview of EEG Research in Early Childhood Education: An International Perspective. Képzés és Gyakorlat. 16. 3. 37-44.

https://doi.org/10.17165/TP.2018.3.4

Martínez, Fernando, Barraza, Claudia, González, Nimrod, González Juan (2016). KAPEAN: Understanding Affective States of Children with ADHD. Journal of Educational Technology and Society. 19. 2. $18-28$.

Noreika, Valdas, Georgieva, Stanimira, Wass, Sam, Leong, Victoria (2020). 14 challenges and their solutions for conducting social neuroscience and longitudinal EEG research with infants. Infant Behavior and Development. 58. 101393.

https://doi.org/10.1016/i.infbeh.2019.101393

Tao Da, Tan Haibo, Wang Hailing, Zhang Xu, Qu Xinga, Zhang Tingru (2019). A Systematic Review of Physiological Measures of Mental Workload. International Journal of Environmental Research and Public Health. 16. 15. 2716.

https://doi.org/10.3390/ijerph16152716

Turner Matthew D, Burnet Darryl H, Turner Jessica A. (2017). Expanding EEG research into the clinic and classroom with consumer EEG systems. Doi: 10.13140/RG.2.2.10917.81126.

Yourick Debra L., Furtado Marcio, Nagode Daniel, Cohn Scott, Tong Lawrence, Bauman Richard A., Robison Chris, Lumley Lucille A. (2007). Studies to evaluate novel neuroprotectants in a rat model of soman exposure reveal episodes of status epilepticus and spontaneous recurrent seizures even with 
initial oxime, atropine and diazepam therapeutics. In: Defence against the effects of chemical hazards: toxicology, diagnosis and medical countermeasures (pp. 20-1-20-12). Meeting Proceedings RTO-MP-HFM-149, Paper 20. Neuilly-sur-Seine, France: RTO.

Wang Ting, Guan Sheng-Uei, Man Ka Lok (2014). EEG eye state identification using incremental attribute learning with time-series classification. Mathematical Problems in Engineering. 1. 9.

https://doi.org/10.1155/2014/365101

Wang Xiao-Jing (2010) Neurophysiological and Computational Principles of Cortical Rhythms in Cognition. Physiological Reviews. 90. 3. 1195-1268.

https://doi.org/10.1152/physrev.00035.2008 